Conference Paper

\title{
Identification and Mapping of Critical Land Level in Probolinggo District Us- ing Geographic Information System (GIS) Techniques (Case Study: Sum- berasih, Wonokerto Sub-district, Bantaran, Maron, Krejengan, Tegal Siwa- lan and Pakuniran)
}

Siswanto*, Purwadi

Agrotechnology Study Program. Faculty of Agriculture, Universitas Pembangunan Nasional “Veteran” Jawa Timur. Indonesia

*Corresponding author:

E-mail:

siswanto.agro@upnjatim.ac.id

\begin{abstract}
Based on research on land damage in 2019 in the highland area of Probolinggo, it was categorized as light to moderate damage. Follow-up research in the middle plains that have the potential to experience land damage due to intensive land use without paying attention to conservation principles, with an indication that the production and income of farmers continue to decline. The research aims to identify the status of critical land and compile a database of critical land for the medium lands of Probolinggo district including Sumberasih, Wonomerto, Bantaran, Maron, Krejengan, Tegalsiwalan, and Pakuniran. The research method for the distribution of critical land using the Geographic Information System is divided into the main activity stages, namely the compilation of databases and data analysis. Database preparation begins with data collection, supporting maps, and literature study. Meanwhile, data analysis used map overlay analysis. The analysis for the preparation of spatial data for critical land consists of 3 stages: overlapping, editing attribute data, and tabular analysis. The level of erosion in the 7 sub-districts of the study area includes very heavy (SB) in the open land of Pakuniran and residential land in Krejengan, the level of gravity on empty land, dryland in Pakuniran, and settlements in Pakuniran, Tegalsiwalan, and Maron. The research area includes 7 districts in Probolinggo which has an area of 36,017.68 ha, with a non-critical status of $15,613.22$ ha $(43.35 \%)$. Critical potential $10,942.66$ ha $(30.38 \%)$, rather critical $8,134.56$ ha $(22.58 \%)$. critical 196.23 ha $(0.54 \%)$ and very critical 1.131 .01 ha $(3.14 \%)$.
\end{abstract}

Keywords: Critical land, GIS, land degradation

\section{Introduction}

Probolinggo District is located on the slopes of the mountains that stretch from West to East namely Mount Semeru. Argopuro. Lamongan and Tengger. Based on observations in the field of land use, it consists of rice fields, dryland Ponds, settlements, and forests. The use of agricultural land is quite intensive so that the potential for land degradation is very large. The emergence of critical land was due to intensive land management without paying attention to the principles of soil and water conservation. Based on Government Regulation (PP) Number 150 of 2000 concerning Control of Soil Damage for Biomass. The government regulation aims to make land-use possible by considering the capability of the land so that the land can be beneficial in a sustainable manner while still producing well and optimally.

\section{How to cite:}

Siswanto, \& Purwadi. (2021). Antimicrobial and mapping of critical land level in Probolinggo District Using Geographic Information System (GIS) techniques (Case Study: Sumberasih, Wonokerto Sub-district, Bantaran, Maron, Krejengan, Tegal Siwalan and Pakuniran). 5th International Seminar of Research Month 2020. NST Proceedings. pages 434-447. doi: 10.11594/ nstp.2021.0964 
Research that has been conducted on the highlands in 2019 shows that the land categorized as lightly damaged and moderately damaged. Further research in the middle land area has the potential to experience land damage due to intensive agricultural land use without paying attention to the principles of soil and water conservation.

One way to identify the existence and distribution of critical land in the Probolinggo district is by utilizing Geographic Information System (GIS) technology. With this technology, it will be easier to analyze and determine the distribution of critical land. Another advantage of digital data is that the process of further map analysis can be carried out quickly and precisely. This condition is very useful for improving the performance of policymakers in making policies related to critical land.

This study aims to identify the critical land status and compile a database system as a space for allocating data on critical land in the middle plains area of the Probolinggo district. The research locations included Sumberasih, Wonomerto, Bantaran, Maron, Krejengan, Tegalsiwalan and Pakuniran districts.

\section{Definition of Critical Land}

The definition of critical land between an institution and another institution is different this is due to differences in the viewpoints of users. Critical land in agriculture is related to land productivity (the ability to produce from a land), whereas, from a forestry and environmental preservation point of view, critical land is related to the function of land as a medium for water management, a medium for the production of forest products and as a medium for flood protection and/or sedimentation downstream Didu (2001).

Critical land according to Government Regulation Number 76 of 2008 in Forest Rehabilitation and Reclamation island that no longer functions as a medium for water management and land productivity elements, disrupting the balance of the watershed ecosystem.

\section{Critical land parameters}

The results of the analysis of several determinants of land criticality produce spatial data on land criticality. Parameters determining critical land-based on Forestry ministerial regulation Number P.32 / Menhut-II / 2009, include land cover, slope, erosion hazard level, and land management. Meanwhile, according to the Regulation of the Director-General of Watershed and Protection Forest Control Number P.3/PDASHL/SET/KUM.1/7/2018. Regarding the Technical Guidelines for Compilation of Spatial Data for Critical Land, including variables: land cover, slope, erosion hazard level, and area/area. This regulation regulates the amount of soil loss (erosion) expressed in tons/ha/year.

\section{Material and Methods Location and Time of Research}

The research location is on medium land covering 7 (seven) Districts with observation points in each district: Sumberasih with an altitude of $406 \mathrm{~m}$ above sea level (asl), Wonomerto with an altitude of $410 \mathrm{~m}$ asl, Bantaran with an altitude of $425 \mathrm{~m}$ asl, Maron with an altitude of $410 \mathrm{~m}$ above sea level, Krejengan with an altitude of $540 \mathrm{~m}$ above sea level, Tegalsiwalan with an altitude of $630 \mathrm{~m}$ above sea level, and Pakuniran with an altitude of $610 \mathrm{~m}$ above sea level. This research was conducted from May - July 2020. The administrative area of the research area presented in Figure 1. 


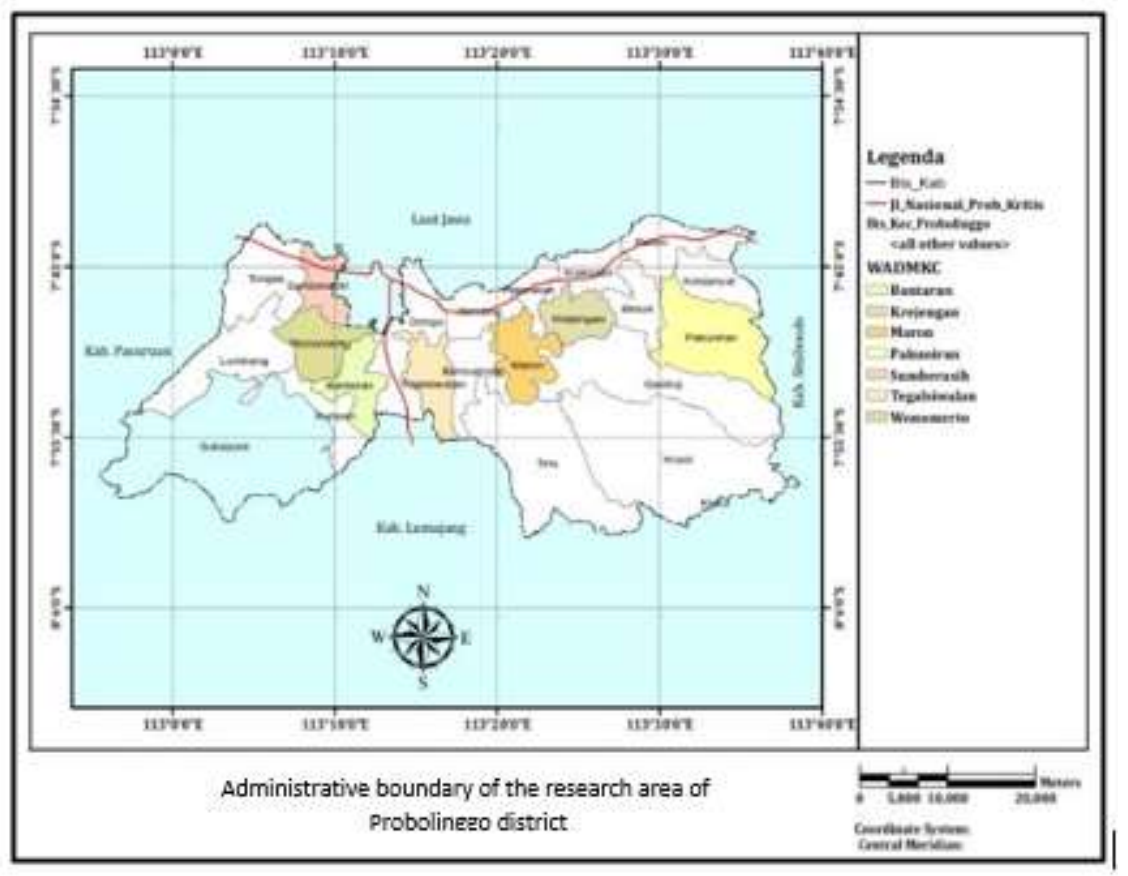

Figure 1. Research location of land critical status in Probolinggo District

\section{Research data}

The data used in this research are measurement data and field observations in each district, land cover maps or land use maps, administrative maps, and slope class maps. The results of the spatial analysis are in the form of land unit maps which are used as a study of the distribution of land criticality and the observation points for biophysical data sampling. Soil biophysical data required such as soil texture, permeability, soil structure class, organic matter, $\mathrm{pH}$, soil electrical conductivity, and soil biology.

\section{Research methods}

The research method is to analyze the distribution of critical land using the Geographic Information System which is divided into main stages, namely: database development and data analysis, which begins with data collection, supporting maps, and literature study.

The analysis used is spatial (spatial) analysis. The technique of overlaying maps analysis is for making studies of administrative spatial, land cover, land use. Erosion maps are made by calculating the amount of soil loss using the general equation for soil loss (PUKT). Illness factor, land cover used spatially through this analysis so that it can be seen locations that have land criticality. Broadly speaking, the stages in spatial analysis for the preparation of spatial data for critical land consist of 3 stages, namely: tumpeng compiling spatial data, editing attribute data, and tabular analysis.

\section{Identification of land criticalities}

Identification of the critical land status by comparing the data obtained from the survey and laboratory analysis data (Appendix 1 Tables 1 and 2). Data resulting from spatial analysis with standard criteria for soil damage based on PP. 150 of 2000, and Regulation of the Director-General of Watershed Control \& Protected Forests Number P.3 / PDASHL / SET / KUM.1 / 7/2018. Regarding Technical Guidelines for Compilation of Critical Land Spatial Data. 
Table 1. Standard criteria for soil damage for dry land

\begin{tabular}{clc}
\hline No & \multicolumn{1}{c}{ Parameters } & Critical threshold \\
\hline 1 & root depth & $<20 \mathrm{~cm}$ \\
2 & surface rock & $>40 \%$ \\
3 & Composition of the sand frac- & $<18 \%$ colloid; loam $/>80 \%$ Coarse Sand \\
4 & tion & $>1.4 \mathrm{~g} / \mathrm{cm}^{3}$ \\
5 & Total Density (BD) & $<30 \% ;>70 \%$ \\
6 & Degree of water release & $<0.7 \mathrm{~cm} / \mathrm{jam} ;>8 \mathrm{~cm} / \mathrm{jam}$ \\
7 & pH $\left(\mathrm{H}_{2} \mathrm{O}\right) 1: 2.5$ & $<4.5 ;>8.5$ \\
8 & Electrical Conductivity (EC) & $>4.0 \mathrm{mS} / \mathrm{cm}$ \\
9 & Redox & $<200 \mathrm{mV}$ \\
10 & The number of microbes & $<10^{2} \mathrm{cfu} / \mathrm{g}$ soils \\
\multicolumn{2}{l}{ Sources: PP No. 150 the Year 2000 }
\end{tabular}

\section{Establishment of land critical status}

The determination of the criticality status of the land is based on combining the land use score with a weight of $60 \%$, the slope factor, and the level of erosion hazard with a weight of $40 \%$. Land use (land cover) scoring was carried out by grouping into land-use classes (land cover) that have been determined by the Director-General of Watershed Control and Protection Forest as in table 2 .

Table 2. Types and class of land cover

\begin{tabular}{|c|c|c|c|c|}
\hline No & Symbol & Land Used & Class & Score \\
\hline 1 & Lanud & Airport & \multirow{12}{*}{1} & \multirow{12}{*}{12} \\
\hline 2 & $A$ & Water Body & & \\
\hline 3 & Rw & Swamp & & \\
\hline 4 & S & Savana & & \\
\hline 5 & $\mathrm{Pm} / \mathrm{Tr}$ & Settlement & & \\
\hline 6 & $\mathrm{Hp}$ & $\begin{array}{l}\text { Primary dry- } \\
\text { land forest }\end{array}$ & & \\
\hline 7 & Sw & Rice fields & & \\
\hline 8 & $\mathrm{Tm}$ & Pond & & \\
\hline 9 & $\mathrm{Hmp}$ & $\begin{array}{l}\text { Primary man- } \\
\text { grove forest }\end{array}$ & & \\
\hline 10 & $\mathrm{Hms}$ & $\begin{array}{l}\text { Secondary } \\
\text { mangrove for- } \\
\text { est }\end{array}$ & & \\
\hline 11 & Hrp & $\begin{array}{l}\text { Primary } \\
\text { swamp forest }\end{array}$ & & \\
\hline 12 & Hrs & $\begin{array}{l}\text { Secondary } \\
\text { swamp forest }\end{array}$ & & \\
\hline
\end{tabular}

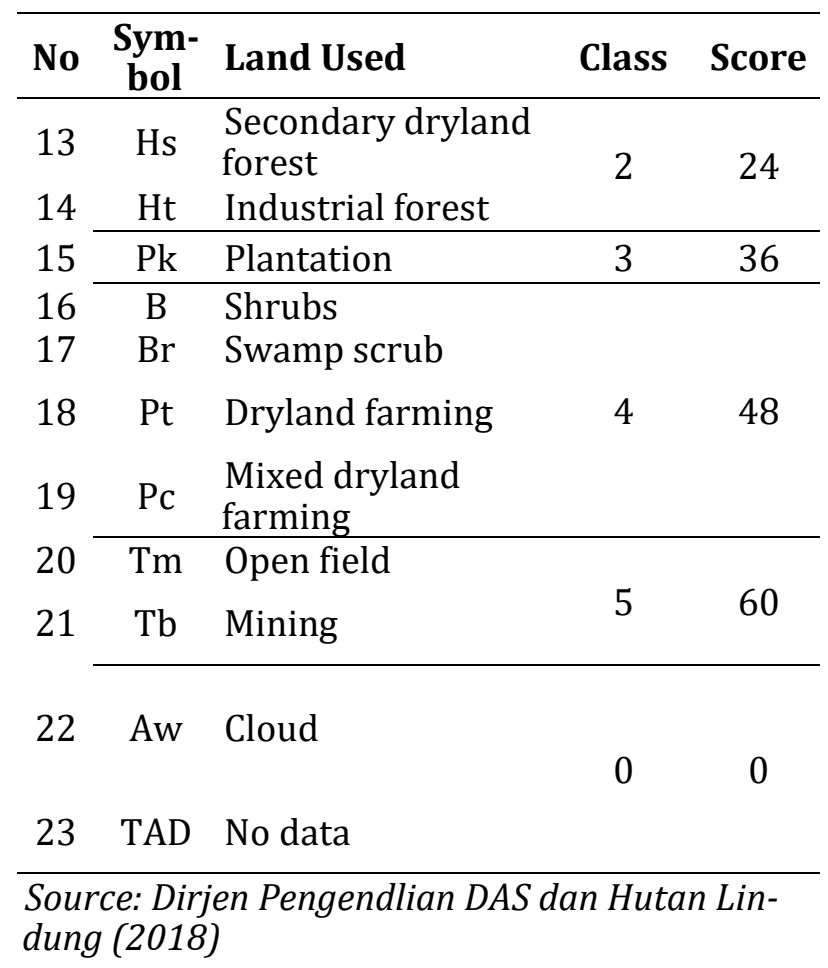

Meanwhile, the erosion score is obtained by calculating the amount of erosion expected by the soil loss equation $\mathrm{E}=\mathrm{R} \times \mathrm{K} \times \mathrm{LS} \times \mathrm{CP}$. Rain erosion is calculated using the equation for monthly rainfall with the following equation: $(\mathrm{Rb}=2.21 \times(\mathrm{Hb}) 1.36$, Erodibility is estimated by the equation $100 \mathrm{~K}=1.292(2,1 \mathrm{M} 1,14(10-4))(12-\mathrm{a})+3.25(\mathrm{~b}-2)+2.5(\mathrm{c}-3))$. The value of the slope factor is based on the slope class issued by the Ministry of Forestry (Nugroho \& Prayogo, 2008) as in table 3 . 
Table 3. LS values based on the slope of the slope

\begin{tabular}{ccll}
\hline Class & Slope $\%$ & & Criteria \\
\hline 1 & $0-8$ & Plat & \\
2 & $>8-15$ & Sloping & \\
3 & $>15-25$ & Slightly Steep & \\
4 & $25-40$ & Steep & \\
5 & $>40$ & Very Steep & \\
\hline
\end{tabular}

Source: Dirjen Pengendlian DAS dan Hutan Lindung (2018)

The CP factor value is determined based on the type of land use and land management, by modifying the Land Cover Vegetation and Plant Management (CP) Factor, which is stated in the Regulation of the Director-General of Watershed Control and Protected Forests of 2018, as in Table 4 .

Table 4. CP Factor scores for various aspects of land management

\begin{tabular}{clc}
\hline No. & \multicolumn{1}{c}{ Land used } & CP \\
\hline 1 & Primary Dryland Forest & 0.001 \\
2 & Secondary Dryland For- & 0.005 \\
& est \\
& Mixed Dry Land Agricul- & 0.5 \\
3 & ture & 0.1 \\
4 & Paddy fields & 1 \\
5 & Airport & 0.001 \\
6 & Conservation Forest & 1 \\
7 & Industry/ Settlements & \\
\hline
\end{tabular}

\begin{tabular}{clc}
\hline No. & \multicolumn{1}{c}{ Land used } & CP \\
\hline 8 & Tourism Area & 1 \\
9 & Mining & 1 \\
& & 0.5 \\
10 & Dry Land Agriculture & \\
11 & Annual Farming & 0.1 \\
12 & $\begin{array}{l}\text { Most Beautiful Livestock and Ag- } \\
\text { riculture }\end{array}$ & 0.1 \\
13 & Plantation & 0.1 \\
\hline \multicolumn{2}{l}{$\begin{array}{l}\text { Source: Director General of Watershed and Protection For- } \\
\text { est Management (2018) }\end{array}$}
\end{tabular}

The amount of land loss due to erosion is in ton/ha/year, then weighted according to the provisions in the regulation of the Director-General of Watershed Control and Protection Forest, as in Table 5.

Table 5. Erosion class score

\begin{tabular}{ccc}
\hline Erosion (ton/ha/year) & Criteria & Score \\
\hline$<15$ & Very Light & 8 \\
$15-60$ & Light & 16 \\
$60-180$ & Moderate & 24 \\
$180-480$ & Heavy & 32 \\
$>480$ & Very Heavy & 40 \\
\hline
\end{tabular}

Source: Director General of Watershed and Protection Forest Management (2018)

The determination of the critical status of the land is carried out by gradually overlaying the map of administrative areas, land use, slope maps, and erosion maps. The attribute table adds a column for the total score that adds up the land use score and the erosion score. The land critical score, which is the sum of the land use score with a weight of $60 \%$ and an erosion score with a weight of $40 \%$, is as in table 6 . 
Table 6. Scores for Land Cover and Erosion Map

\begin{tabular}{lccccc}
\hline Land Used & Class & Score & Erosion & Score & Score Total \\
\hline $\begin{array}{l}\text { Swamp } \\
\text { Savana }\end{array}$ & 1 & 12 & $<15$ & 8 & 20 \\
$\begin{array}{l}\text { Primary Dryland Forest } \\
\text { Secondary Dryland Forest }\end{array}$ & 2 & 24 & $>15-60$ & 16 & 40 \\
$\begin{array}{l}\text { Plantation Forest } \\
\text { Plantation }\end{array}$ & 3 & 35 & $>60-180$ & 24 & 60 \\
\hline $\begin{array}{l}\text { Shrubs } \\
\text { Mixed Dry Land Farming }\end{array}$ & 4 & 48 & $>180-480$ & 32 & 80 \\
\hline $\begin{array}{l}\text { Open Land } \\
\text { Mining }\end{array}$ & 5 & 60 & $>480$ & 40 & 100 \\
\hline
\end{tabular}

Source: Director General of Watershed and Protection Forest Management (2018)

To assess the criticality status of the overlapping results of the two maps, the land criticality score obtained which is the sum of the two scores above. The criticality score based on the criticality class is as in Table 7.

Table 7. Land criticality score

\begin{tabular}{cc}
\hline Number & Criticality Score \\
\hline 1 & $20-36$ \\
2 & $>36-52$ \\
3 & $>52-68$ \\
4 & $>68-84$ \\
5 & $>84-100$ \\
\hline
\end{tabular}

Source: Dirjen Pengendlian DAS dan Hutan Lindung (2018)

The map of the critical status of an area is determined from the results of overlaying maps of administrative area maps, land use maps, and erosion maps. Meanwhile, a critical land status map in an administrative area is obtained by overlaying a map of the critical status of an administrative area with a land slope map outside the forest area. The score of land criticality analysis in an area obtained 5 classes of land criticality, namely Non-critical (TK), Potential Critical (PK), Somewhat Critical (AK), Critical (K), and Very Critical (SK), based on the scoring of the critical status of the land and slope field. The combination to get the critical land status is based on Table 8. 
Table 8. Scores for land critical analysis outside the forest zone

\begin{tabular}{|c|c|c|c|c|c|}
\hline \multirow{2}{*}{ Slope (\%) } & \multicolumn{5}{|c|}{ Criticality Score } \\
\hline & $0-36$ & $>36-52$ & $>52-68$ & $>68-84$ & $>84-100$ \\
\hline $0-8$ & $\mathrm{NC}$ & $\mathrm{NC}$ & $\mathrm{PC}$ & SC & SC \\
\hline$>8-15$ & NC & PC & SC & SC & SC \\
\hline$>15-25$ & PC & SC & SC & C & VC \\
\hline$>25-40$ & PC & SC & SC & C & VC \\
\hline$>40$ & SC & SC & $\mathrm{SC}$ & C & VC \\
\hline
\end{tabular}

Source: Dirjen Pengendlian DAS dan Hutan Lindung (2018)

$N C=$ no Critical, $P C=$ Potential Critical, $A C=$ Slight Critical, $C=$ Critical, $V C=$ Very Critical

\section{Spatial Data Overlay}

Geographic Information System application in this study is direct in the preparation of databases and data analysis. The spatial data collected is arranged in layers according to the data group. Meanwhile, tabular data were tabulated according to their spatial groups. Spatial analysis by overlapping is carried out on layers to obtain new areas that meet the specified criteria. The transparency data layer, land cover, land use, and management using spatial analysis to find new areas that meet the critical land criteria. Broadly speaking, the stages in spatial analysis for the preparation of spatial data on critical lands consist of 3 stages, namely: tumpeng compiling spatial data attribute data editing and tabular analysis.

Using ArcGIS 10.6 software. ArcMap can be stacked easily. Additional tools provided by ArcGIS 10.6, namely Geoprocessing, make it easier to integrate spatial data with join facilities, cut, reshaping, intersect, etc. The overlapping process begins with a land cover layer with the slope class then the results overlaid with an erosion layer and so on for other layers.

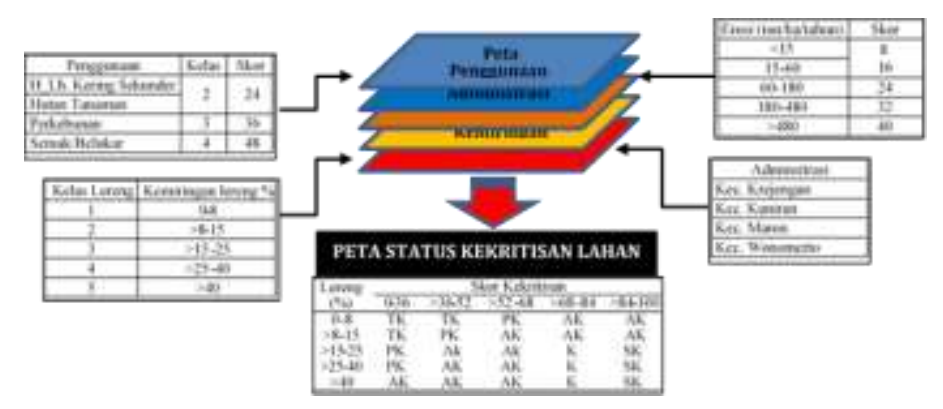

Figure 2. The flow of determining the criteria for land criticality in Probolinggo District.

\section{Attribute Data Editing}

Editing attribute data, in general, is adding a new column (field) to the attribute layer resulting from the overlap-add up all the critical land criterion scores and enter them into the new column that has been creating. Addition of all critical land parameter scores using the equation: $(60 \% *$ Land cover score $)+(40 \% *$ Erosion score $)$. To accommodate the sum in the Tot Score Field and Critical Class field. The Tot Score field is a field that will be filled with the total score of critical land criteria in a unit of analysis (polygon overlay results), while Critical Class is a field that will be filled with the classification of critical land as a result of tabular analysis. 


\section{Tabular analysis}

The results of attribute data editing, especially the sum of the land criticality parameter scores. Then analyzed to classify the level of criticality of land in each new layer (overlapping results) several parameters of land criticality). Steps taken to determine land that are included in the categories of Non-critical, Critical Potential, Somewhat Critical, Critical, and Very Critical. is to perform a query (using query builder) with query formula ([Tot Score] $>84 \&$ [slope] $>25$ ) for very critical status and query formula ([Tot Score] $>64 \&$ [slope] $>15$ ) for critical status, formula query ([Tot Score] $>52 \&$ [slope] $>8$ ) for somewhat critical status, query formula ([Tot Score] $>36 \&$ [slope] $>$ 8) for critical potential status and query formula ([Tot Score] $<36 \&$ [slope] $<8$ ) a for non-critical status.

\section{Results and Discussion}

\section{Slope of land}

a. The slope of the Pakuniran Sub-district

Pakuniran Sub-district has the highest slope between $25-40 \%$, a class of steep slopes with an area of $\pm 21,910.05$ ha, a slope of $8-15 \%$ with an area of $\pm 1,710.25$ ha, and flat with a slope of 0 $8 \%$ covering an area of $\pm 1,102.54$ ha.

b. The slope of the land in the Krejengan Sub-district

Krejengan Sub-district is included in the flat slope class, namely $0-8 \%$ with a land area of 3,903.6 ha.

c. Slope of Land in Maron Sub-district

Maron Sub-district has the highest slope between 8-15\%, a gentle slope class with an area of \pm 1.801 .72 ha, and a flat $0-8 \%$ slope of $\pm 3,339.82$ ha.

d. The slope of Tegalsiwalan Sub-distric

Tegalsiwalan Sub-district has the highest slope between 8-15\%, a gentle slope class with an area of $\pm 2,895.93 \mathrm{ha}$, and a flat $0-8 \%$ slope of $\pm 1,596.51$ ha.

e. Slope of Land, Bantaran Sub-district

Bantaran Sub-district has the highest slope between 8-15\%, a gentle slope class with an area of $\pm 2,184.14 \mathrm{ha}$, and a flat $0-8 \%$ slope of $\pm 2,221.42 \mathrm{ha}$.

f. The slope of Wonomerto Sub-district

Wonomerto Sub-district has the highest slope between 8-15\%, gentle slope class with an area of $\pm 3,709.4$ ha, and a flat slope of $0-8 \%$ covering an area of $\pm 1,091.94$ ha.

g. The slope of the land in the Sumberasih Sub-district

Sumberasih Sub-district has the highest slope between 8-15\%, gentle slope class with an area of \pm 513.29 ha, and a flat slope of $0-8 \%$ covering an area of \pm 2732.38 ha.

The research area is group into 5 classes of slope slopes as shown in Figure 3.

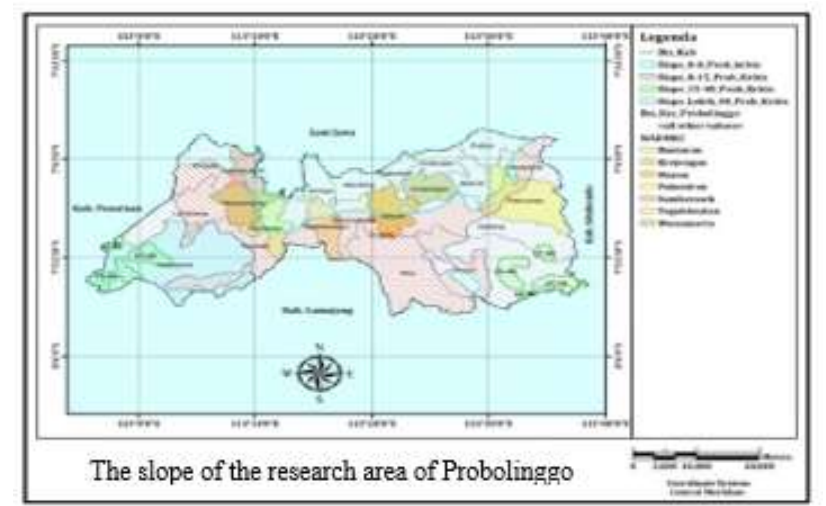

Figure 3. The distribution of land slopes in the study area 


\section{Land cover}

Land cover is the biophysical cover of the earth's surface which is the result of regulation, activity, and human treatment carried out on certain types of land cover to carry out production, change, or maintenance activities in the area. The results of the analysis of land cover in the 7 subdistricts of the study area were grouped into the forest, rice fields, settlements, ponds, empty land, and Tegal. The percentage and area of each cover in 7 sub-districts are presented in table 9 and figure 4 .

Table 9. Percentage and Extent of Land Cover in 7 Districts in the study area

\begin{tabular}{|c|c|c|c|c|c|c|c|}
\hline Sub District & Coverage & Area & $\%$ & Sub District & Coverage & Area & $\%$ \\
\hline \multirow[t]{4}{*}{ Sumberasih } & Field Rice & 2420.47 & 78.17 & & & & \\
\hline & Pond & 110.99 & 3.58 & Maron & Field Rice & 4253.78 & 82.73 \\
\hline & Settlement & 564.94 & 18.25 & & Settlement & 557.07 & 10.83 \\
\hline & & 3096.40 & & & Forest & 330.69 & 6.43 \\
\hline \multirow[t]{5}{*}{ Wonomerto } & Field Rice & 4083.99 & 85.06 & & & 5141.54 & \\
\hline & Dryland & 64.66 & 1.35 & Krejengan & Field Rice & 3103.17 & 79.50 \\
\hline & Settlement & 88.25 & 1.84 & & Settlement & 408.53 & 10.47 \\
\hline & Forest & 564.44 & 11.76 & & Forest & 391.90 & 10.04 \\
\hline & & 4801.34 & & & & 3903.60 & \\
\hline \multirow[t]{5}{*}{ Bantaran } & Field Rice & 3694.21 & 83.85 & Pakuniran & Field Rice & 1432.36 & 14.28 \\
\hline & Dryland & 89.92 & 2.04 & & Forest & 6980.74 & 69.62 \\
\hline & Settlement & 165.37 & 3.75 & & Open Land & 825.67 & 8.23 \\
\hline & Forest & 456.06 & 10.35 & & Dryland & 436.01 & 4.35 \\
\hline & & 4405.56 & & & Settlement & 352.75 & 3.52 \\
\hline \multirow[t]{4}{*}{$\begin{array}{l}\text { Tegalsiwa- } \\
\text { lan }\end{array}$} & Settlement & 151.90 & 3.38 & & & 10027.53 & \\
\hline & Field Rice & 4244.35 & 94.48 & Amount & & 35868.41 & \\
\hline & Forest & 96.19 & 2.14 & \multirow{2}{*}{\multicolumn{3}{|c|}{ Source: Result analysis land coverage }} & \\
\hline & & 4492.44 & & & & & \\
\hline
\end{tabular}

From table 9 the land cover for each sub-district in the study area shows the percentage and area are not the same. Pakuniran sub-district is dominated by forests of $69.62 \%$ or an area of $6980.74 \mathrm{ha}$, and the lowest residential cover is $3.52 \%$, or an area of 352.75 ha. The land cover in the Krejengan sub-district was dominated by paddy fields of $79.5 \%$ or an area of 3103.17 ha, and the lowest was forest cover of $10.04 \%$ or an area of 392.9 ha. Maron sub-district is dominated by $82.73 \%$ or an area of 4253.78 ha by rice fields, and forests only occupy $6.43 \%$ or an area of 330.69 ha. For Tegalsiwan, Bantaran, Wonomerto, and Sumberasih sub-districts, each of them were dominated by rice field cover of $94.48 \%$ ( $4244.35 \mathrm{ha}$ ), 83.85\% (3694.21 ha), 85.06\% (4083.99 ha), respectively. ha) and $78.17 \%$ or (2420.47 ha). 


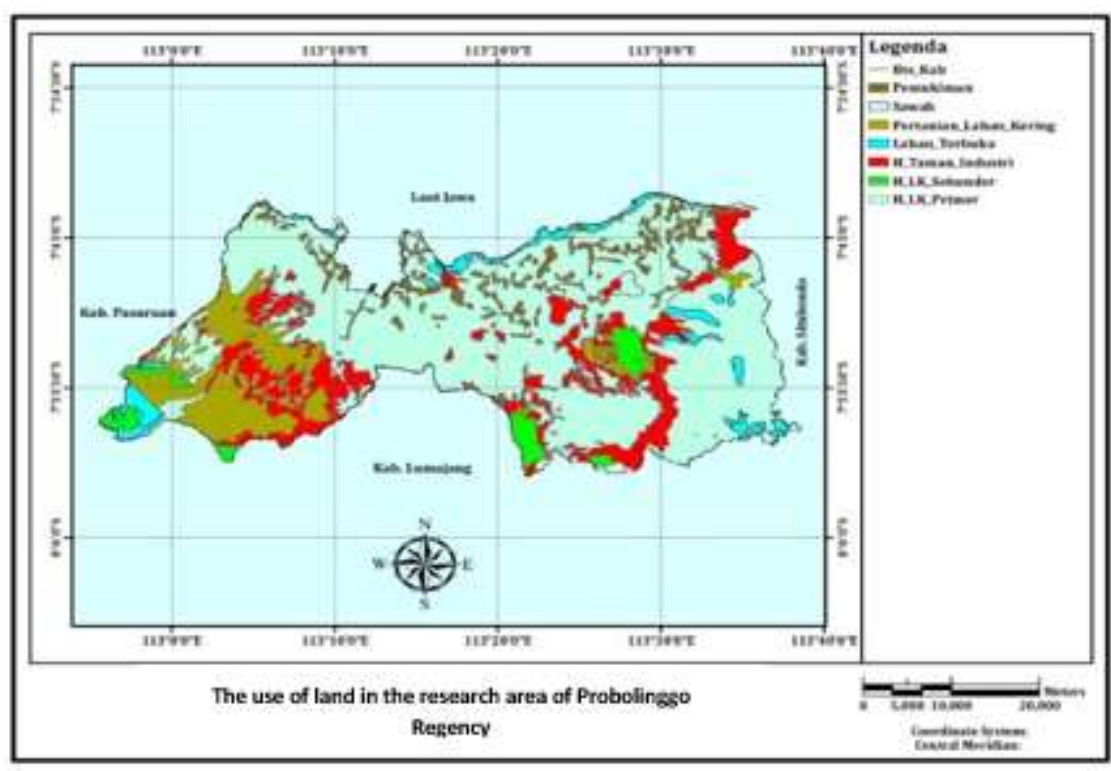

Figure 4. Distribution of land cover in the study area

\section{Loss of soil (Erosion)}

The amount of soil loss was estimated using the general equation for soil loss developed by Wischmeier and Smith (1978), namely E = R x K x L x S x C x P. research is presented in table 10, and figure 5.

Table 10. Amount of soil erosion in the study area

\begin{tabular}{|c|c|c|c|c|c|c|c|}
\hline Sub District & Land Used & $\begin{array}{c}\text { Erosion } \\
\text { (ton/ha/year) }\end{array}$ & $\%$ & Sub District & Land Used & $\begin{array}{c}\text { Erosion } \\
\text { (ton/ha/year) }\end{array}$ & $\%$ \\
\hline \multirow[t]{4}{*}{ Sumberasih } & Field Rice & 16.76 & 11.65 & & & & \\
\hline & Pond & 9.97 & 6.93 & Maron & Field Rice & 19.57 & 12.26 \\
\hline & Settlement & 117.11 & 81.42 & & Settlement & 130.89 & 82.03 \\
\hline & & 143.84 & & & Forest & 9.11 & 5.71 \\
\hline \multirow[t]{5}{*}{ Wonomerto } & Field Rice & 19.82 & 21.60 & & & 159.57 & \\
\hline & Settlement & 51.38 & 56.00 & Krejengan & Field Rice & 132.47 & 9.43 \\
\hline & Dryland & 15.41 & 16.80 & & Settlement & 1246.20 & 88.69 \\
\hline & Forest & 5.14 & 5.60 & & Forest & 26.49 & 1.89 \\
\hline & & 91.75 & & & & 1405.16 & \\
\hline \multirow[t]{5}{*}{ Bantaran } & Field Rice & 34.33 & 8.43 & Pakuniran & Field Rice & 8.38 & 0.05 \\
\hline & Settlement & 98.10 & 24.10 & & Settlement & 1356.23 & 8.40 \\
\hline & Dryland & 171.67 & 42.17 & & Dryland & 5518.24 & 34.19 \\
\hline & Forest & 103.00 & 25.30 & & Forest & 638.46 & 3.96 \\
\hline & & 407.10 & & & Open Land & 8619.91 & 53.40 \\
\hline \multirow[t]{3}{*}{$\begin{array}{l}\text { Tegalsiwa- } \\
\text { lan }\end{array}$} & Field Rice & 68.82 & 14.49 & & & 16141.22 & \\
\hline & Settlement & 336.79 & 70.93 & & Amount & 18823.44 & \\
\hline & Forest & $\begin{array}{r}69.19 \\
474.80\end{array}$ & 14.57 & & ult erosion & & \\
\hline
\end{tabular}

From table 10, it can be seen that the amount of erosion for each sub-district in the study area shows the percentage and area that are not the same. Pakuniran Subdistrict, the largest erosion occurred in open land, amounting to $52.07 \%$ of the total erosion in the sub-district, and the lowest 
was in the use of paddy fields by $2.55 \%$. The largest erosion incidence in the Krejengan sub-district was in land use for settlements of $61.36 \%$ and the lowest was in forest use by $1.25 \%$. Maron subdistrict experienced soil erosion of $58.06 \%$ on residential land, while the lowest soil erosion was $13.25 \%$ in paddy fields. The largest amount of land loss in the Tegalsiwalan sub-district was in the use of paddy fields by $61.81 \%$ and the lowest was on forest land, namely $2.29 \%$. For Bantaran and Wonomerto districts, the largest loss of land was in paddy fields, namely $39.86 \%$ and $62.69 \%$. Meanwhile, the Sumberasih sub-district experienced the largest erosion in residential use, namely 79.89\%.

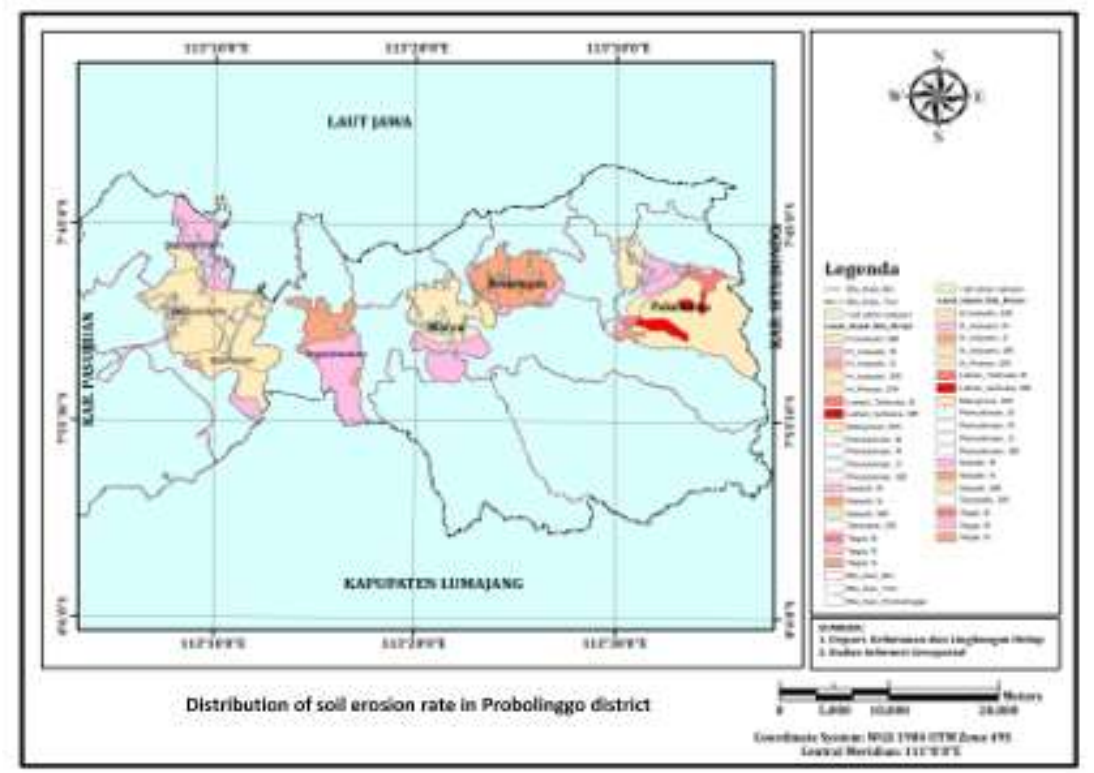

Figure 5. Erosion hazard levels in the Seven Research Area Districts

\section{Determination of Land Damage Status}

Utilizing a Geographic Information System (GIS) facilitates an effective and efficient needs analysis and action for forest and watershed land rehabilitation (DAS). so that it can eliminate the shortcomings that occur due to manual activities. Another advantage of using digital data is that the synthesis process and further analysis can be carried out quickly and precisely. This condition is very useful for improving the performance of policymakers related to forest and land management (Lukas et al., 2018).

The data needed in this study is a topographic map. contour map. land map. administrative area map. Landsat satellite imagery. land use map. with a map scale of 1: 50,000. For the analysis and synthesis of quantitative data, it is done by: a) classifications. scoring and weighting with the scale and criteria as stipulated in the Decree of the Director-General of RRL No. 041 / Kpts / V / 1998. and b). which is followed by gradual overlapping of each map layer (slope class-map, land cover map, land distribution map, management map). so that the resulting critical land classification (Nugroho \& Prayogo, 2008).

The determination of the critical land status was obtained using ArcMap GIS version 10.6 by combining and overlaying the layers of land cover, land slope, erosion hazard, and administrative areas or areas. The distribution of critical land in the 7 sub-districts of Probolinggo district on medium plains is strongly influenced by geology and geomorphology in the area. The land conditions in the 7 sub-districts are influenced by volcanic activity and the wet climate so that the soil is very fertile. so that land use is dominated by agricultural cultivation (both wet and dry land).

In terms of physiography. the research area is divided into two areas. namely: (1) Medium plain area located in the northern part of Mount Bromo and northwest of Mount Argopuro. Given 
the fertile soil conditions. This area is widely used for agriculture. (2) Lowland areas extending to the Java Sea.

Based on spatial analysis with overlay technique and scoring of critical land determination parameters. obtained spatial data of critical land for 7 sub-districts in the Probolinggo district. The results of the analysis show that the research area has a land area of 36,017.68 ha, with the following classification: non-critical area of $15,613.22$ ha (43.35\%). Critical potential 10,942.66 ha (30.38\%), rather critical area of 8,134.56 ha (22.58\%). a critical area of 196.23 ha $(0.54 \%)$ and a very critical area of 1,131.01 ha (3.14\%), with the distribution of land not critical. The potentials for critical, somewhat critical, critical, and very critical in each sub-district are shown in Table 11. Meanwhile, the distribution of critical land in each sub-district is presented in Figure 6.

Table 11. Area distribution and percentage of land status with various uses in the study area

\begin{tabular}{|c|c|c|c|c|c|c|c|c|c|c|c|c|c|}
\hline $\begin{array}{l}\text { Sub Dis- } \\
\text { trict }\end{array}$ & $\begin{array}{l}\text { Land } \\
\text { Used } \\
\end{array}$ & Slope & $\begin{array}{l}\text { Area } \\
\text { (ha) }\end{array}$ & & $\begin{array}{l}\text { Sta- } \\
\text { tus }\end{array}$ & $\%$ & $\begin{array}{l}\text { Sub Dis- } \\
\text { trict }\end{array}$ & $\begin{array}{l}\text { Land } \\
\text { Used }\end{array}$ & Slope & $\begin{array}{l}\text { Area } \\
\text { (ha) }\end{array}$ & & $\begin{array}{l}\text { Sta- } \\
\text { tus }\end{array}$ & $\%$ \\
\hline \multirow[t]{5}{*}{ Sumberasih } & \begin{tabular}{|l} 
Settle- \\
ment
\end{tabular} & $0-8$ & 564.94 & 2732.38 & $\mathrm{NC}$ & 84.19 & Maron & \begin{tabular}{|l} 
Settle- \\
ment
\end{tabular} & $0-8$ & 491.71 & 3009.13 & $\mathrm{NC}$ & 58.53 \\
\hline & Pond & $0-8$ & 110.99 & & $\mathrm{NC}$ & & & \begin{tabular}{|l|} 
Field \\
Rice \\
\end{tabular} & $0-8$ & 2517.42 & & $\mathrm{NC}$ & \\
\hline & $\begin{array}{l}\text { Man- } \\
\text { grove }\end{array}$ & $0-8$ & 149.27 & & $\mathrm{NC}$ & & & \begin{tabular}{|l} 
Indus- \\
try For- \\
est \\
\end{tabular} & $0-8$ & 330.69 & 2132.41 & PC & 41.47 \\
\hline & $\begin{array}{l}\text { Field } \\
\text { Rice }\end{array}$ & $0-8$ & 1907.18 & & $\mathrm{NC}$ & & & \begin{tabular}{|l|} 
Settle- \\
ment
\end{tabular} & 8-15 & 65.36 & & PC & \\
\hline & $\begin{array}{l}\text { Field } \\
\text { Rice }\end{array}$ & $8-15$ & 513.29 & 513.29 & $\mathrm{PC}$ & 15.81 & & \begin{tabular}{|l|} 
Field \\
Rice \\
\end{tabular} & 8-15 & 1736.36 & & PC & \\
\hline \multirow[t]{5}{*}{ Wonomerto } & $\begin{array}{l}\text { Settle- } \\
\text { ment }\end{array}$ & $0-8$ & 88.25 & 1091.94 & $\mathrm{NC}$ & 22.74 & Krejengan & \begin{tabular}{|l|} 
Field \\
Rice \\
\end{tabular} & $0-8$ & 3103.17 & 3511.7 & $\mathrm{NC}$ & 89.96 \\
\hline & \begin{tabular}{|l|l|} 
Field \\
Rice \\
\end{tabular} & $0-8$ & 1003.69 & & $\mathrm{NC}$ & & & \begin{tabular}{|l|} 
Settle- \\
ment
\end{tabular} & $0-8$ & 408.53 & & $\mathrm{NC}$ & \\
\hline & $\begin{array}{l}\text { Indus- } \\
\text { try For- } \\
\text { est } \\
\end{array}$ & 8-15 & 564.44 & 629.1 & SC & 13.10 & & \begin{tabular}{|l} 
Indus- \\
try For- \\
est \\
\end{tabular} & $0-8$ & 391.9 & 391.9 & SC & 10.04 \\
\hline & Dryland & $8-15$ & 64.66 & & SC & & $\begin{array}{l}\text { Pakuni- } \\
\text { ran }\end{array}$ & \begin{tabular}{|l|} 
Field \\
Rice \\
\end{tabular} & $0-8$ & 946.53 & 1450.14 & NC & 14.46 \\
\hline & \begin{tabular}{|l} 
Field \\
Rice \\
\end{tabular} & $8-15$ & 3080.3 & 3080.3 & PC & 64.16 & & \begin{tabular}{|l}
$\begin{array}{l}\text { Settle- } \\
\text { ment }\end{array}$ \\
\end{tabular} & $0-8$ & 156.01 & & $\mathrm{NC}$ & \\
\hline \multirow[t]{6}{*}{ Bantaran } & $\begin{array}{l}\text { Indus- } \\
\text { try For- } \\
\text { est } \\
\end{array}$ & 8-15 & 456.06 & 545.98 & SC & 12.39 & & \begin{tabular}{|l|} 
Dry- \\
land \\
Forest \\
\end{tabular} & 8-15 & 347.6 & & $\mathrm{NC}$ & \\
\hline & Dryland & $8-15$ & 89.92 & & SC & & & \begin{tabular}{|l|} 
Field \\
Rice \\
\end{tabular} & $8-15$ & 485.83 & 682.57 & PC & 6.81 \\
\hline & $\begin{array}{l}\begin{array}{l}\text { Settle- } \\
\text { ment }\end{array} \\
\end{array}$ & $0-8$ & 165.37 & 2221.42 & $\mathrm{NC}$ & 50.42 & & \begin{tabular}{|l|}
$\begin{array}{l}\text { Settle- } \\
\text { ment }\end{array}$ \\
\end{tabular} & $8-15$ & 196.74 & & PC & \\
\hline & $\begin{array}{l}\text { Field } \\
\text { Rice }\end{array}$ & $0-8$ & 1828.08 & & $\mathrm{NC}$ & & & \begin{tabular}{|l|} 
Dry- \\
land \\
Forest \\
\end{tabular} & $\begin{array}{l}25- \\
40\end{array}$ & 5887.5 & 6567.58 & SC & 65.50 \\
\hline & \begin{tabular}{|l} 
Field \\
Rice \\
\end{tabular} & $0-8$ & 227.97 & & $\mathrm{NC}$ & & & $\begin{array}{l}\text { Open } \\
\text { Land }\end{array}$ & 8-15 & 130.67 & & SC & \\
\hline & $\begin{array}{l}\text { Field } \\
\text { Rice }\end{array}$ & 8-15 & 1638.16 & 1638.16 & PC & 37.18 & & $\begin{array}{l}\text { Indus- } \\
\text { try For- } \\
\text { est }\end{array}$ & $8-15$ & 549.41 & & SC & \\
\hline
\end{tabular}

To be continued 


\begin{tabular}{|l|l|l|l|l|l|l|l|l|l|l|l|l|l|}
\hline $\begin{array}{l}\text { Tegalsiwa- } \\
\text { lan }\end{array}$ & $\begin{array}{l}\text { Settle- } \\
\text { ment }\end{array}$ & $0-8$ & 151.9 & 1596.51 & NC & 35.54 & & $\begin{array}{l}\text { Indus- } \\
\text { try For- } \\
\text { est }\end{array}$ & $\begin{array}{l}25- \\
40\end{array}$ & 196.23 & 196.23 & C & 1.96 \\
\hline & $\begin{array}{l}\text { Field } \\
\text { Rice }\end{array}$ & $0-8$ & 1444.61 & & NC & & & $\begin{array}{l}\text { Dry- } \\
\text { land }\end{array}$ & $\begin{array}{l}25- \\
40\end{array}$ & 436.01 & 1131.01 & VC & 11.28 \\
\hline & $\begin{array}{l}\text { Indus- } \\
\text { try For- } \\
\text { est }\end{array}$ & $8-15$ & 96.19 & 2895.93 & PC & 64.46 & & $\begin{array}{l}\text { Open } \\
\text { Land }\end{array}$ & $\begin{array}{l}25- \\
40\end{array}$ & 695.00 & & VC & \\
\hline & $\begin{array}{l}\text { Field } \\
\text { Rice }\end{array}$ & $8-15$ & 2799.74 & & PC & & \multicolumn{3}{|l|}{$\begin{array}{l}\text { NC = No Critical, PC = Potential Critical, SC = Slightly Critical, } \\
\text { C = Critical, VC= Very Critical }\end{array}$} \\
\hline
\end{tabular}

Most of the areas that are not critical are in the low to moderate plains. namely rice fields and tegal. This category of land occupies around $43.35 \%$ with the Pakuniran sub-district having the largest distribution of around $33.09 \%$ and the smallest being the Tegalsiwalan sub-district at $5.58 \%$. This category of land also needs serious attention, especially for tegal. Tegal land often has no vegetation cover during the dry season, and most landowners are reluctant to manage it. This will encourage new potential critical land. Meanwhile, land with a somewhat critical category occupies an area proportion of $19.82 \%$ of the total area. Utilization of land which is categorized as somewhat critical needs to be taken seriously so as not to spur degradation of land quality. Land with critical and very critical categories occupies an area proportion of approximately $2.32 \%$ of the total area.

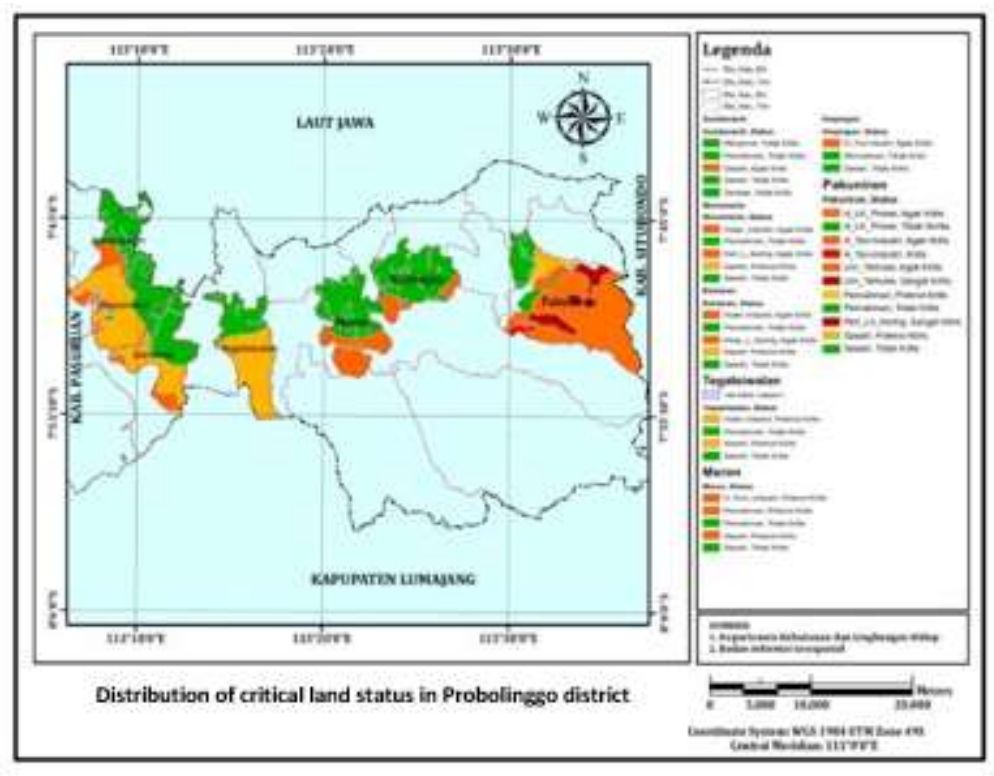

Figure 6. Distribution of land critical status in the study area

\section{Conclusion}

Based on the results of the identification of the criticality status of the land, it can be concluded that: soil erosion in Pakuniran District is the largest in open land 52.07\% (8,619.91 ton / ha / yr) and the lowest is $2.55 \%$ ( 422.19 ton / ha / yr). th), in the Krejengan sub-district the largest is in residential land $61.36 \%(8,545.04$ tonnes / ha / year) and the lowest is in forest land $1.25 \%$ (174.27 toh / ha / yr), the largest in Maron District is residential land 58, 06\% (4,748.96 tonnes / ha / yr) and the lowest was in paddy fields 13.25\% (1,083.81 ton / ha / yr, in Tegalsiwalan subdistrict, the largest was $61.81 \%$ (3,568.11 ton / ha / th) and the lowest was in forest land, namely 
$2.29 \%$ (132.45 ton / ha / year). For Bantaran and Wonomerto sub-districts, the largest was in rice fields, namely 39.86\% (858.58 ton / ha / year) and $62.69 \%$ (2942.65 tonnes / ha / yr). While Sumberasih sub-district the largest erosion was in settlements $79.89 \%$ (1365.72 tonnes / ha / yr).

The level of erosion in the 7 sub-districts of the study area includes very heavy (SB) in the open land of Pakuniran District and residential land in Krejengan, the level of gravity on empty land, tegal in Pakuniran sub-district, and housing in the sub-district. Pakuniran, Kec.Tegalsiwalan and Kec Maron.

The research area which covers 7 sub-districts in the Probolinggo district has an area of $36,017.68$ ha, with non-critical status covering an area of 15,613.22 ha (43.35\%). Critical potential $10,942.66$ ha $(30.38 \%)$, rather critical area of $8,134.56$ ha $(22.58 \%)$. a critical area of 196.23 ha $(0.54 \%)$ and a very critical area of 1.131 .01 ha $(3.14 \%)$.

\section{References}

Didu. (2001). Analysis of the position and role of institutions and policies in the process of critical land formation. Journal of Environmental Technology, 2 (1), 93-105. https://journal.ipb.ac.id/index.php/itanah

Lukas R. R., Veronica, A. K., \& Hendriek, H. K. (2018). Identification and mapping of critical land using geographic information system technology. Spatial Journal, 5(1), 1-8.

Ministry of Forestry. (2009). Regulation of the Minister of Forestry of the Republic of Indonesia Number: P. 32 / Menhut - II / 2009 concerning procedures for the preparation of a technical plan for rehabilitation of forest and watershed lands (RTkRHL-DAS). Jakarta (ID): Ministry of Forestry.

Nugroho. S. P., \& Prayogo, T. (2008). Application of GIS for the preparation and analysis of critical land in the Kuantan Das Agam Management Area Unit. West Sumatra Province. J. Tech. Ling, 9(2), 130-140 Jakarta.

Regulation of the Director General of Watershed and Protected Forest Control Number P.3 / Pdashl / Set / Kum.1 / $7 / 2018$ concerning Technical Guidelines for Compiling Spatial Data on Critical Lands.

Regulation of the State Minister for the Environment. No. 20 of 2008. concerning Technical Regulations on Minimum Service Standards (SPM) in the Environmental Sector of Provincial and Regency / City Areas. 